\title{
Dietary supplement intake during pregnancy; better safe than sorry?
}

Citation for published version (APA):

de Boer, A., Bast, A., \& Godschalk, R. (2018). Dietary supplement intake during pregnancy; better safe than sorry? Regulatory Toxicology and Pharmacology, 95, 442-447.

https://doi.org/10.1016/j.yrtph.2018.03.014

Document status and date:

Published: 01/06/2018

DOI:

10.1016/j.yrtph.2018.03.014

Document Version:

Publisher's PDF, also known as Version of record

Document license:

Taverne

Please check the document version of this publication:

- A submitted manuscript is the version of the article upon submission and before peer-review. There can be important differences between the submitted version and the official published version of record.

People interested in the research are advised to contact the author for the final version of the publication, or visit the DOI to the publisher's website.

- The final author version and the galley proof are versions of the publication after peer review.

- The final published version features the final layout of the paper including the volume, issue and page numbers.

Link to publication

\footnotetext{
General rights rights.

- You may freely distribute the URL identifying the publication in the public portal. please follow below link for the End User Agreement:

www.umlib.nl/taverne-license

Take down policy

If you believe that this document breaches copyright please contact us at:

repository@maastrichtuniversity.nl

providing details and we will investigate your claim.
}

Copyright and moral rights for the publications made accessible in the public portal are retained by the authors and/or other copyright owners and it is a condition of accessing publications that users recognise and abide by the legal requirements associated with these

- Users may download and print one copy of any publication from the public portal for the purpose of private study or research.

- You may not further distribute the material or use it for any profit-making activity or commercial gain

If the publication is distributed under the terms of Article $25 \mathrm{fa}$ of the Dutch Copyright Act, indicated by the "Taverne" license above, 
Commentary

\title{
Dietary supplement intake during pregnancy; better safe than sorry?
}

\author{
Alie de Boer $^{\mathrm{a}, *}$, Aalt Bast ${ }^{\mathrm{b}, \mathrm{c}}$, Roger Godschalk ${ }^{\mathrm{b}}$ \\ a Food Claims Centre Venlo, Maastricht University Campus Venlo, Faculty of Humanities and Sciences, Venlo, The Netherlands \\ ${ }^{\mathbf{b}}$ Department of Pharmacology and Toxicology, Faculty of Health Medicine and Life Sciences, Maastricht University, Maastricht, The Netherlands \\ ${ }^{\mathrm{c}}$ Maastricht University Campus Venlo, Faculty of Humanities and Sciences, Venlo, The Netherlands
}

\section{A R T I C L E I N F O}

\section{Keywords:}

Fetal programming

Nutrivigilance

Dietary supplements

Novel food

European food law

Food safety

\begin{abstract}
A B S T R A C T
Consumption of dietary supplements and specifically niche products such as supplements targeting pregnant women is increasing. The advantages of dietary supplementation during pregnancy with folic acid have been established, but health effects of many other supplements have not been confirmed. EU and US legislation on dietary supplements requires the product to be safe for the direct consumer, the mother. Long-term health effects for the fetus due to fetal programming (in utero adaptation of the fetal epigenome due to environmental stimuli such as supplementation) are not taken into account. Such epigenetic alterations can, however, influence the response to health challenges in adulthood. We therefore call for both conducting research in birth cohorts and animal studies to identify potential health effects in progeny of supplement consuming mothers as well as the establishment of a nutrivigilance scheme to identify favorable and adverse effects post-marketing. The acquired knowledge can be used to create more effective legislation on dietary supplement intake during pregnancy for safety of the child. Increasing knowledge on the effects of consuming supplements will create a safer environment for future mothers and their offspring to optimize their health before, during and after pregnancy.
\end{abstract}

\section{Introduction}

The popularity of dietary supplements, in this paper defined as sources of concentrated micro- or macronutrients, is rising together with an increasing interest of consumers in potential health enhancing foods (Euromonitor International, 2015; Menrad, 2003; Teichner and Lesko, 2013). Especially niche products, such as dietary supplements that target women of reproductive age and pregnant women, increased their market share over the past decade. For example, from 2010 to 2015, the multivitamin market yearly grew 2 to 19 percent in the eight countries with the highest sales of multivitamins (UK, Brazil, USA, Russia, Mexico, Italy, South Korea and China). In the UK alone, the sales of multivitamins targeting pregnant women grew approximately two percent in these five years, ending up representing $17 \%$ of the total multivitamin market in the UK (Schmidt, 2015). Although the availability of epidemiological data is limited, cross-sectional and cohort studies suggest an increase in daily use of supplements (Kim et al., 2014; Radimer et al., 2004; Sullivan et al., 2009). Different studies report that females use different dietary supplements more often than men and especially those persons with increased interest in health were more regularly consumers of dietary supplements (Bailey et al., 2011; Dickinson et al., 2014; Radimer et al., 2004; Rock, 2007). Additionally, in specific subgroups including athletes and long-term cancer survivors at reproductive age, the use of dietary supplements has increased (Knapik et al., 2016; Velicer and Ulrich, 2008; Wardenaar et al., 2016).

The beneficial effect of dietary supplementation before and during pregnancy has only been established for folic acid: folic acid is important for growth and development of both the fetus and maternal tissues and a sufficient intake of folic acid can be guaranteed by supplementing the diet (De-Regil et al., 2015; EFSA NDA Panel, 2009; Eichholzer et al., 2006; Kaiser and Allen, 2008). In various countries, foods are (required to be) fortified with folic acid, whilst the European strategy is to advise the target group (women with the intention to become pregnant and pregnant women) to supplement their diet (Czeizel et al., 2013). Whereas fortification can reach a broader public, it is suggested to expose the general public to too high amounts of folic acid while a large part of the target group may still not meet their recommended daily intake (Czeizel et al., 2013; Osterhues et al., 2013). Women of childbearing age and pregnant women have been reported to increasingly use dietary supplements with other ingredients such as the omega-3 polyunsaturated fatty acid docohexaenoic acid (DHA), calcium, vitamin D, zinc and multivitamins, but also with herbal ingredients such as Echinacea and ginger (Buppasiri et al., 2015; Cave et al., 2016; De-Regil et al., 2016; Imhoff-Kunsch et al., 2012; Ota et al.,

\footnotetext{
* Corresponding author. Food Claims Centre Venlo, Maastricht University Campus Venlo, Faculty of Humanities and Sciences, Maastricht University, P.O. Box 8, 5900 AA Venlo, The Netherlands.

E-mail address: a.deboer@maastrichtuniversity.nl (A. de Boer).
} 
2015; Picciano and McGuire, 2009; Tsui et al., 2001). However, when a woman is not malnourished during pregnancy, the use of supplements other than folic acid is not proven to be beneficial and its consumption is questionable (Darnton-Hill and Mkparu, 2015; Ladipo, 2000). The maternal diet before and during pregnancy, and even during breastfeeding, has been shown to induce phenotypic changes in offspring which may affect the offspring's health status. Obviously, dietary components can elicit such alterations through the placenta and postpartum through the nutritional values of breast milk, but these studies did not unveil clear cut relationships between the intake of specific nutrients by the mother and health status of their children (Hambidge et al., 2014; Netting et al., 2014; Ramakrishnan et al., 2012).

The safety of such dietary supplements consumed during pregnancy is often not specifically studied (Friedman, 2000; Schweitzer, 2006). Although teratogenic effects of compounds are important in safety assessments (European Parliament and Council of the European Union, 2015), the effects of supplement intake on the long-term health of the fetus seems to be addressed to a much lesser extent. It is however generally acknowledged that the dietary intake (both the quality and the quantity of the diet) and dietary status of pregnant women can affect the development of the fetus which subsequently influences health in adult life (Godfrey and Barker, 2001; Lillycrop and Burdge, 2014). This is exemplified by dietary supplementation with folic acid during pregnancy: whilst supplementation in the first trimester of pregnancy is beneficial for health of the offspring, using folic acid supplements later in pregnancy is suggested to increase the risk to develop allergic diseases and asthma (Eichholzer et al., 2006; Whitrow et al., 2009).

With the increasing awareness about fetal development being influenced by the maternal diet, this paper illustrates how food supplement safety is regulated and why long-term safety is important to be taken into account in safety regulations.

\section{Regulating dietary supplement safety}

Safety is key in the regulation of dietary supplements. Rules and regulations dealing with dietary supplement safety do however not seem to consider the consequences that consuming such products can have on the offspring of the consumer. In Europe, dietary supplements are regulated by Directive 2002/46/EC, the so-called Food Supplement Directive (FSD) (European Parliament and Council of the European Union, 2002). The FSD defines food supplements as 'concentrated sources of nutrients or other substances with a nutritional or physiological effect', which are aimed to supplement the normal diet (European Parliament and Council of the European Union, 2002). Medicinal products are specifically excluded under this Directive. Since dietary supplements are categorized as food products, these supplements must comply with other relevant food legislation. The framework regulation concerning foods, the General Food Law (GFL), describes food safety as one of the general principles for food products to be allowed to be placed on the market (European Parliament and Council, 2002). Although the GFL does not provide a definition for food safety, food is described to be unsafe when a product is (a) injurious to health or (b) unfit for human consumption (European Parliament and Council, 2002). In determining whether a product is injurious to health, Article 14 (4) (a) of the GFL specifies that effects on subsequent generations should also be assessed (European Parliament and Council, 2002), next to the short- and/or long-term effects on the direct consumer. Since no specific requirements are however mentioned, this article leaves room for interpretation.

In the United States, the Dietary Supplement Health and Education Act of 1994 (DSHEA) regulates food supplements separately from conventional foods and food additives (Dietary Supplement Health and Education Act of 1994; U.S. Congress). The DSHEA defines supplements as 'any product which contains one or more dietary ingredients such as vitamins, minerals, herbs or other botanicals, amino acids or other ingredients used to supplement the diet' (Dietary Supplement Health and Education Act of 1994, n.d.). Although food products should be safe when they are available for sale, no specific safety dossier is required before dietary supplements are placed on the market. The DSHEA gives the Food and Drug Administration (FDA) in the USA the authority to safeguard the public from unsafe products (Dietary Supplement Health and Education Act of 1994, n.d.; U.S. Food and Drug Administration, 2014). Therefore, adequate information must be provided to the FDA before a new dietary ingredient can be brought to market and when the FDA shows that the dietary ingredient poses a 'significant or unreasonable risk' to consumer safety, the product can be removed from the market (Dietary Supplement Health and Education Act of 1994, n.d.). Currently, however, the long-term effects of dietary supplements consumed during pregnancy or during breastfeeding are insufficiently known to make a proper decision about potential risks and consumer safety. In Europe, only new ingredients or products produced by new techniques are subject to the safety review of the European Food Safety Authority (EFSA), a crucial aspect in the pre-market authorization by the European Commission for such a novel food under the Novel Food Regulation (Regulation (EU) 2015/2283) (European Parliament and Council of the European Union, 2015; Turck et al., 2016). The European Commission has described in their recommendation that the wholesomeness of food products, influenced by i.a. the nutritional, toxicological and metabolic properties of a product, is key in assessing the authorization of a novel food (European Commission, 1997; Turck et al., 2016). Next to considering the nutritional implications of a novel food, this recommendation also suggests to take short and long term effects of consuming a novel food into account and to pay specific attention therein to groups with specific nutritional requirements, such as pregnant and lactating women (European Commission, 1997). The health effects of offspring in later life do however not seem to be taken into consideration when safety is tested. As the effects of the maternal dietary status and maternal consumption during pregnancy on the development of the fetus become more apparent, the question arises how these findings can be incorporated in legislation, and specifically in dietary supplement regulation.

\section{Fetal programming}

Before birth, the fetus is affected by various environmental factors such as maternal dietary status, food intake or the intake of dietary supplements by the mother (Fig. 1). The fetus is thought to adapt to these in utero circumstances by making changes to the epigenome that are potentially necessary for survival, which can persist in later life (Gicquel et al., 2008; Godfrey and Barker, 2001; Vanhees et al., 2014). In short, the epigenome includes various chemical changes to the structure of DNA without changing the underlying DNA sequence. These chemical changes can be either on the DNA bases (e.g., methylation of cytosine in CpG sequences) or on proteins that are involved in folding the DNA (e.g., histone modifications). These epigenetic modifications are involved in regulating gene expression and therefore affect growth and tissue differentiation, especially in the developing child. Moreover, these modifications can be passed down to the offspring via transgenerational epigenetic inheritance. The DNA sequence in the genome is largely static within an individual, but the epigenome is dynamic and can be altered by environmental conditions, especially by dietary habits (Vanhees et al., 2014). These adaptations to the environmental circumstances by the fetal epigenome may result in altered structures and functioning of the organism, which is also known under different terms, including 'phenotype induction', 'fetal programming' (Burdge et al., 2007; Gicquel et al., 2008; Godfrey et al., 2013; Godfrey and Barker, 2001; Vanhees et al., 2014) or the 'Developmental origins of (adult) health and disease' (DOHAD) hypothesis (47-50). Since different organ systems develop on various critical time points, environmental stimuli or triggers can influence the development of the fetus differently (Al-Ghazali et al., 1989; Barker, 2012; Chmurzynska, 2010; 


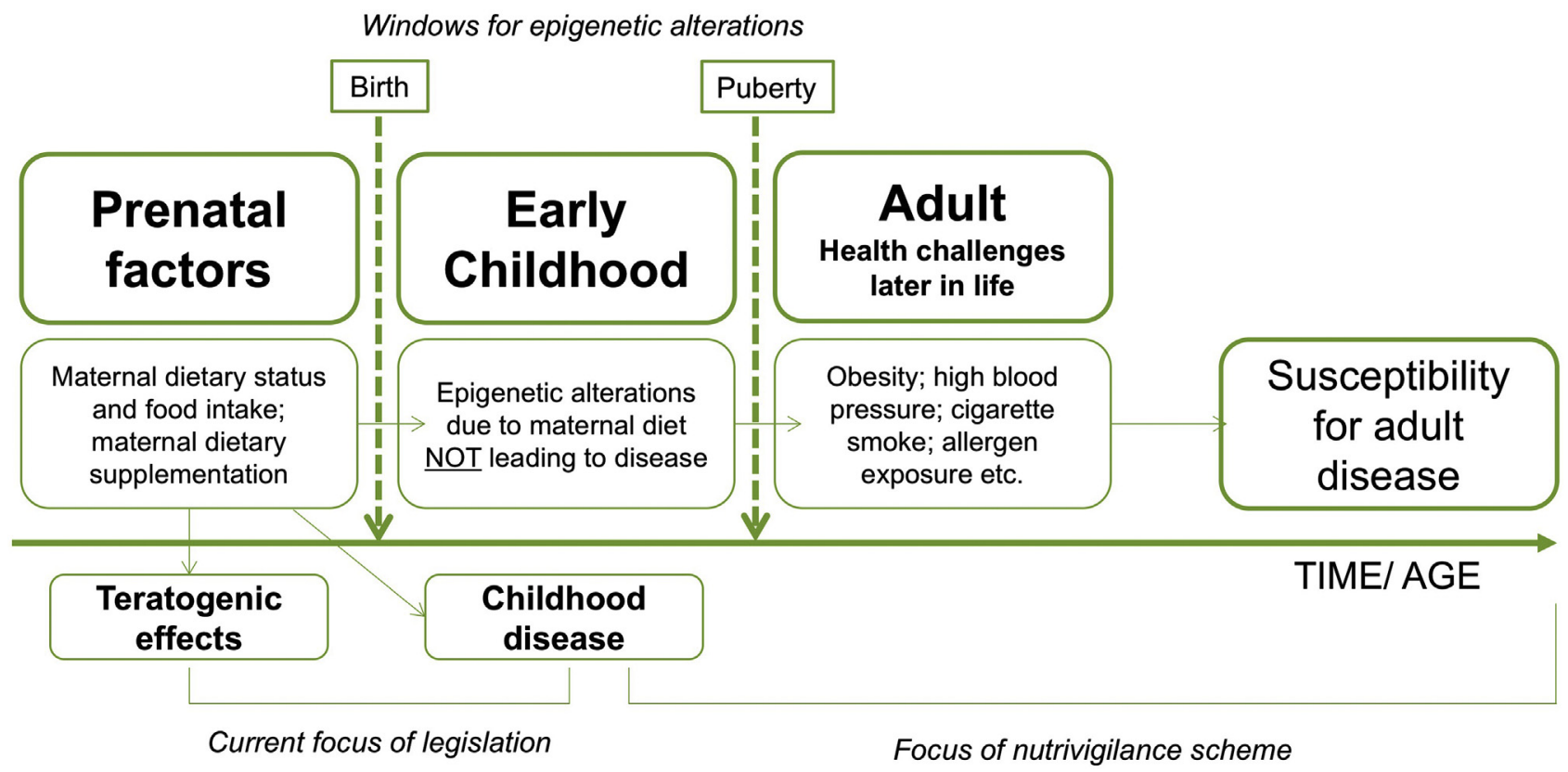

Fig. 1. How prenatal environmental factors could influence the response to health challenges in adulthood.

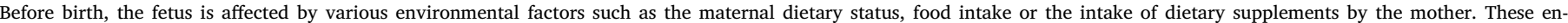

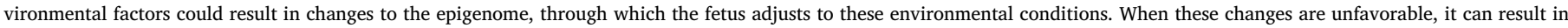

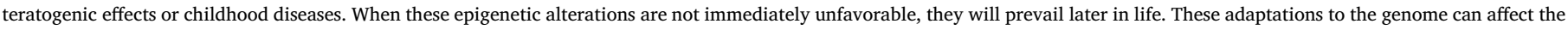

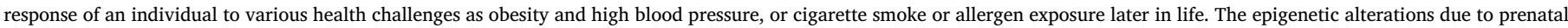

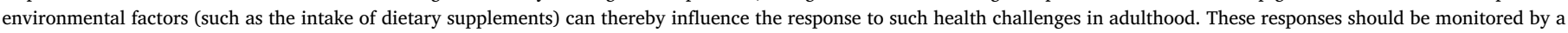

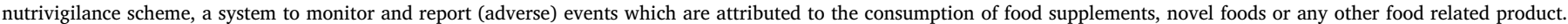

\section{Godfrey and Barker, 2001).}

As depicted in Fig. 1, stable alterations to the fetal epigenome prevail later in life and can influence the response to environmental stimuli in adulthood (Brenseke et al., 2013; Gicquel et al., 2008; Godfrey et al., 2007). When later in life environmental conditions interact with the altered epigenome, this mismatch of environmental stimuli with the altered epigenome can increase the risk of developing diseases. An example of such a mismatch was shown in children that were in utero during the Dutch Famine (hunger winter of 1944-1945). These children have an increased risk for obesity, not because of the protein and caloric deficiency only, but because they additionally encountered a Western type of diet later in life leading to a mismatch between the in utero environment and the environment in adulthood (Gluckman, 2004; Grandjean, 2008; Roseboom et al., 2001). Animal models of obesity (mothers consuming hyper-caloric diets) also demonstrated negative effects in offspring such as increased systolic blood pressure and higher fasting plasma insulin (Brenseke et al., 2013; Roseboom et al., 2011; Vickers et al., 2000), indicating that not only under-nutrition, but also over-nutrition can have 'programming' consequences.

\section{Dietary supplementation and fetal programming}

Various reviews have shown that the maternal dietary intake influences the health status of offspring (Burdge et al., 2007; Chmurzynska, 2010; Lillycrop, 2011). Micronutrients are well known modulators of the epigenome (for instance the effect of vitamin D on the epigenome (Fetahu et al., 2014) and various roles of nutrients in epigenetic processes reviewed in (Choi and Friso, 2010)). These reviews however mainly focus on the potential negative effects of deficiencies of the maternal diet or negative consequences following the intake of a sub-optimal maternal diet, whereas the current trend towards optimizing health is also focusing on women of childbearing age not necessarily heaving deficiencies (Schmidt, 2015). Supplement use by pregnant women is therefore expected to rise. The following four short cases illustrate why also intake of dietary supplements with concentrated nutrients in a healthy maternal dietary status and the offspring's health, should somehow be taken into account in future safety regulations. Evidence for the programming effect of folic acid is mainly coming from studies in humans, whereas the long term effects of certain flavonoids (e.g., quercetin and genistein) on offsprings' health originates predominantly from animal studies.

\subsection{Folic acid}

Since 1992, dietary supplementation with folic acid is recommended to decrease the risk on neural tube defects (Eichholzer et al., 2006; Gezondheidsraad, 2008). Although this effect of folic acid has been established by epidemiological studies, the exact effect of folic acid on the multistep process of developing the human neural tube is however still not completely understood (Osterhues et al., 2013). Folic acid can for instance act as a co-enzyme and affects the construction and repair of DNA (Czeizel et al., 2013). The supplementation of 0.4 $\mathrm{mg}$ /day folic acid during the first trimester of pregnancy is considered as safe for both the women and their unborn children and it should be noted that the widely recommended use of folic acid before and during pregnancy is undisputed to minimize the risk for neural tube defects as well as other congenital malformations (De-Regil et al., 2015; Eichholzer et al., 2006). Supplements consumed by the mother before or during the fetal development could however affect the fetal epigenome (Pauwels et al., 2017). Various cohort studies and reviews suggest that maternal supplementation with folic acid in late pregnancy can lead to an increased risk for developing asthma or other (allergic) diseases in childhood. However, these data are postulated by studies of varying quality and results are inconclusive (Greenop et al., 2014; Håberg et al., 2009; Magdelijns et al., 2011; Martinussen et al., 2012; Schüz et al., 2007; Wang et al., 2015; Whitrow et al., 2009). Still, epidemiological studies performed so far, do not consider the presence of potential triggers or challenges, for instance exposure to allergens, and whether children of mothers who took folic acid supplements react 
differently to these allergens. Additionally, a recent study by Pauwels et al. (2017) suggests that maternal dietary or supplemental intake of methyl-group donors (including folate) can influence the infant's DNA methylation patterns in genes related to metabolism, growth, appetite regulation, and maintenance of DNA methylation reactions. Thus, although maternal folic acid supplementation during pregnancy is undisputed, a follow up at later stages in the child's life is warranted to further optimize the dose of folic acid or to optimally select the timewindow during pregnancy at which additional intake of folic acid should be recommended.

\subsection{Quercetin}

Dietary intake of supplements containing flavonoids and antioxidants in general is popular amongst pregnant women (Barenys et al., 2016). Consequences of dietary supplementation with the flavonoid quercetin on the offspring's health have been established in several animal studies (Vanhees et al., 2013, 2012; 2011b). Quercetin is a dietary antioxidant, found mainly in onions, apples and tea, which is claimed to have various beneficial health effects as antioxidant and anti-inflammatory properties (Aherne and O'Brien, 2002; Boots et al., 2008; Vanhees et al., 2012). The average daily dietary intake of quercetin in humans with a Western type of diet is 4-68 mg per day (Skibola and Smith, 2000), but a much higher intake can be reached because the daily dose of quercetin supplements lies between 200 and $1800 \mathrm{mg}$ quercetin (manufacturers' recommendations) (Egert et al., 2008; Mennen et al., 2005). These high dose supplements are freely available in pharmacies and drugstores. Therefore, daily quercetin supplementation, which results in increased plasma quercetin levels (Egert et al., 2008), can lead to increased exposures of the fetus to high concentrations of quercetin and its metabolites. Feeding very high doses of quercetin $(333 \mathrm{mg} / \mathrm{kg}$ feed) to pregnant mice did not appear to be teratogenic to their fetuses (Prater et al., 2008), but long term health effects have been described: in mice, the maternal consumption of quercetin is shown to upregulate the gene expression of enzymatic antioxidants in offspring and the response of hepatic cells to oxidative stress seems to be altered (Vanhees et al., 2013, 2012). This could theoretically improve the health status of the offspring by decreasing oxidative stress markers, as well as potentially protecting against induced DNA adduct formation (Vanhees et al., 2012, 2011b). On the other hand, relatively high prenatal concentrations of quercetin were also shown to lead to increased iron storage in the liver, which could put the offspring at risk for a toxic iron overload (Vanhees et al., 2011b).

\subsection{Phyto-estrogens}

Adults consuming modest amounts of soy-containing foods have a total daily isoflavone intake of 1-9 mg. However, people who consume large amounts of soy products, like vegetarians, have a higher intake of isoflavones such as genistein and daidzein. In Asian countries the daily intake of isoflavones can reach $20-40 \mathrm{mg}$, because of the high consumption of soy (Skibola and Smith, 2000). Intake of genistein supplements is becoming increasingly popular, especially for women, because it is suggested to result in decreased breast cancer risk (Coward et al., 1993). The manufacturers of supplements recommend a dose of up to 6 tablets of 25-100 mg per day. Additionally, it should be noted that the metabolism of these isoflavones is different in the fetus, and as a result, fetal cord blood contains higher concentrations of for instance genistein than maternal blood (Coward et al., 1993). Intake by young children can also be high, when they are being fed with soy-based formulas (also see the American Academy of Pediatrics statement on Use of Soy Protein-Based Formulas in Infant Feeding from 2008 (Bhatia and Greer, 2008)). However, there is concern about the intake of isoflavones like genistein during pregnancy, because it mimics the human hormone estrogen (therefore it is called a phyto-estrogen). Animal studies indeed indicate that intake of genistein during pregnancy changes the epigenetic landscape of offspring (Dolinoy et al., 2006) with subsequent changes in gene expression (Vanhees et al., 2011a). Moreover, maternal intake of genistein has been related to early onset of puberty in female offspring and alters the development of breast tissue, potentially leading to increased breast cancer risk in offspring at older ages (Hilakivi-Clarke et al., 2002; n.d.; Warri et al., 2008).

\subsection{Multi micronutrient supplementation}

Recently, a Cochrane systematic review on the safety of multi micronutrient supplement intake during pregnancy was published (Haider and Bhutta, 2015). Most of the studies that were included in the analyses were carried out in low and middle-income countries, where micronutrient deficiency is common among women of reproductive age. It was concluded that supplementation of pregnant women is beneficial with regard to preventing low birth weight and small for gestational age (SGA) pregnancies, whereas in studies that involved pregnant women of Western countries no such beneficial effects were found. Although the authors correctly conclude that interventions with micronutrients during pregnancy should focus on developing countries, it may also lead to additional intake of micronutrients by pregnant women in Western countries, because high intake of micronutrients is generally considered to be safe; better safe than sorry. However, in that same Cochrane review, safety was only assessed on basis of perinatal health only (e.g., preeclampsia, preterm births, maternal anemia, maternal and neonatal mortality, congenital abnormalities etc.), whereas long time health could not be studied. Taking into account the phenomenon of developmental programming, claiming safety of relatively high doses of micronutrients by supplementation may be premature. How should regulators thus deal with this uncertainty?

\section{Epigenetic modulation in safety regulation}

Long term effects of dietary supplements are thought to be mediated via epigenetic mechanisms. The role of epigenetics in reproductive toxicity is discussed in a recent report on the 2015 ECETOC workshop 'The Role of Epigenetics in Reproductive Toxicity', and the use of epigenetic findings in legislation was one major point of discussion (European Centre for Ecotoxicology and Toxicology of Chemicals, 2015). However, current knowledge is too limited and therefore legislative acts have not incorporated this aspect of safety yet.

Since the consumption of dietary supplements does not immediately give rise to adverse effects, it would not be realistic to ban these products form the market until such effects are fully identified. It would therefore be helpful to keep track of these potential negative effects via a nutrivigilance scheme: a system in which adverse events that are attributed to food supplement intake or any other product related to food can be reported (ANSES - French Agency for Food Environmental and Occupational Health and Safety, 2014; Rihouey-Robini, 2014). In response to the thalidomide-affair in the 1960s, where birth defects in children were caused by thalidomide intake during pregnancy, socalled pharmacovigilance systems were developed to report adverse drug reactions after the drug was placed on the market (de Boer et al., 2015). A nutrivigilance scheme, where reports concerning adverse responses following food supplement or functional food consumption can be filed by health professionals, producers and distributors, has so far only been established in France (ANSES - French Agency for Food Environmental and Occupational Health and Safety, 2014; RihoueyRobini, 2014). By establishing a specific system to report adverse events and incidents with various food products as food supplements and novel foods, potential risks can be identified and thereby the scheme can contribute to consumer safety (Fig. 1). 


\section{Future perspectives}

The consumption of supplements by women of childbearing age and pregnant women is expected to rise (Schmidt, 2015). The limited epidemiological data available indicate that many pregnant women consume dietary supplements and this number is thought to increase (Radimer et al., 2004; Sullivan et al., 2009). Although supplementing the diet with folic acid has proven health benefits, many other supplements used during pregnancy are currently not proven to be beneficial, unless they are used to compensate for deficiencies. With the maternal diet affecting the fetal genome through developmental programming, the consequences of supplementing should not be underestimated. We do not suggest that consuming dietary supplements endanger the health of the fetus, yet recognize the current lack of knowledge on the long-term health effects of the maternal diet, and more specifically supplements, on offspring. Next to a nutrivigilance scheme, currently ongoing birth-cohorts and animal studies could help to identify potential adverse and favorable health effects in progeny of supplement consuming mothers.

Birth-cohorts could be very helpful in discovering and possibly quantifying relationships between dietary intake of the mother and potential adverse or beneficial health effects in progeny. Other additional information on fetal programming could originate from animal studies, in which it is possible to consider the effects of specific environmental stimuli on the adapted and maturated genome. In the study design, the consumption of dietary supplements by pregnant animals could be followed by exposure of the mature offspring to environmental stimuli including smoking, exposure to chemicals or use of pharmaceutical products. Although such studies could be helpful in identifying long term effects of prenatal exposure to dietary supplements, results obtained by animal studies can never fully clarify the effects found in humans. Therefore, the ultimate effects can only be evaluated by combining results obtained in animal and human studies with postmarketing events found via a nutrivigilance monitoring scheme.

Although foods are generally considered to be safe, in most cases the safety of these products in pregnancy is not required to be tested and therefore not established (Friedman, 2000; Schweitzer, 2006). This current lack of knowledge on safety and the need for scientific evidence regarding the health effects on offspring give rise to our call to develop a nutrivigilance scheme, by which adverse and favorable effects due to the consumption of specifically dietary supplements can be identified. Increasing knowledge on the effects of consuming supplements will create more effective legislation and thereby a safer environment for future mothers to optimize the health of their children before and during pregnancy.

\section{Conflicts of interest}

No conflicts of interest.

\section{Transparency document}

Transparency document related to this article can be found online at http://dx.doi.org/10.1016/j.yrtph.2018.03.014.

\section{References}

Aherne, S.A., O'Brien, N.M., 2002. Dietary flavonols: chemistry, food content, and metabolism. Nutrition 18, 75-81. http://dx doi.org/10.1016/S0899-9007(01)00695-5.

Al-Ghazali, W., Chita, S.K., Chapman, M.G., Allan, L.D., 1989. Evidence of redistribution of cardiac output in asymmetrical growth retardation. BJOG An Int. J. Obstet. Gynaecol. 96, 697-704. http://dx.doi.org/10.1111/j.1471-0528.1989.tb03285.x.

ANSES - French Agency for Food Environmental and Occupational Health \& Safety, 2014. Nutrivigilance, a Scheme Devoted to Consumer Safety [WWW Document].

Bailey, R.L., Gahche, J.J., Lentino, C.V., Dwyer, J.T., Engel, J.S., Thomas, P.R., Betz, J.M., Sempos, C.T., Picciano, M.F., 2011. Dietary supplement use in the United States, 2003-2006. J. Nutr. 141, 261-266. http://dx.doi.org/10.3945/jn.110.133025.

Barenys, M., Masjosthusmann, S., Fritsche, E., 2016. Is intake of flavonoid-based food supplements during pregnancy safe for the developing Child? A literature review.
Curr. Drug Targets 18, 196-231.

Barker, D.J.P., 2012. Sir Richard Doll lecture. Developmental origins of chronic disease Publ. Health 126, 185-189. http://dx.doi.org/10.1016/j.puhe.2011.11.014.

Bhatia, J., Greer, F., 2008. Use of soy protein-based formulas in infant feeding. Pediatrics 121, 1062-1068. http://dx.doi.org/10.1542/peds.2008-0564.

Boots, A.W., Haenen, G.R.M.M., Bast, A., 2008. Health effects of quercetin: from antioxidant to nutraceutical. Eur. J. Pharmacol. 585, 325-337.

Brenseke, B., Prater, M.R., Bahamonde, J., Gutierrez, J.C., 2013. Current thoughts on maternal nutrition and fetal programming of the metabolic syndrome. J. Pregnancy 2013, 368461.

Buppasiri, P., Lumbiganon, P., Thinkhamrop, J., Ngamjarus, C., Laopaiboon, M., Medley, N., 2015. Calcium supplementation (other than for preventing or treating hypertension) for improving pregnancy and infant outcomes. Cochrane Database Syst. Rev. 2http://dx.doi.org/10.1002/14651858.CD007079.pub3. CD007079.

Burdge, G.C., Hanson, M.A., Slater-Jefferies, J.L., Lillycrop, K.A., 2007. Epigenetic regulation of transcription: a mechanism for inducing variations in phenotype (fetal programming) by differences in nutrition during early life? Br. J. Nutr. 97 1036-1046. http://dx.doi.org/10.1017/S0007114507682920.

Cave, et al., 2016. Vitamin supplementation in pregnancy. Drug Therapeut. Bull. http:// dx.doi.org/10.1136/dtb.2016.7.0414. dtb.2016.7.0414.

Chmurzynska, A., 2010. Fetal programming: link between early nutrition, DNA methylation, and complex diseases. Nutr. Rev. 68, 87-98. http://dx.doi.org/10.1111/j. 1753-4887.2009.00265.x.

Choi, S.-W., Friso, S., 2010. Epigenetics: a new bridge between nutrition and health. Adv. Nutr. 1, 8-16. http://dx.doi.org/10.3945/an.110.1004.

Coward, L., Barnes, N.C., Setchell, K.D.R., Barnes, S., 1993, Genistein, daidzein, and their.beta.-glycoside conjugates: antitumor isoflavones in soybean foods from American and Asian diets. J. Agric. Food Chem. 41, 1961-1967. http://dx.doi.org/ 10.1021/jf00035a027.

Czeizel, A., Dudás, I., Vereczkey, A., Bánhidy, F., 2013. Folate deficiency and folic acid supplementation: the prevention of neural-tube defects and congenital heart defects. Nutrients 5, 4760-4775.

Darnton-Hill, I., Mkparu, U., 2015. Micronutrients in pregnancy in low- and middle-income countries. Nutrients 7, 1744-1768.

De-Regil, L.M., Palacios, C., Lombardo, L.K., Peña-Rosas, J.P., 2016. Vitamin D supplementation for women during pregnancy. Cochrane Database Syst. Rev. 1http://dx. doi.org/10.1002/14651858.CD008873.pub3. CD008873.

De-Regil, L.M., Peña-Rosas, J.P., Fernández-Gaxiola, A.C., Rayco-Solon, P., 2015. Effects and safety of periconceptional oral folate supplementation for preventing birth defects. Cochrane Database Syst. Rev. 12http://dx.doi.org/10.1002/14651858. CD007950.pub3. CD007950.

de Boer, A., van Hunsel, F., Bast, A., 2015. Adverse food-drug interactions. Regul. Toxicol Pharmacol. 73, 859-865.

Dickinson, A., Blatman, J., El-Dash, N., Franco, J.C., 2014. Consumer usage and reasons for using dietary supplements: report of a series of surveys. J. Am. Coll. Nutr. 33, 176-182. http://dx.doi.org/10.1080/07315724.2013.875423.

Dietary Supplement Health and Education Act of 1994, n.d.

Dolinoy, D.C., Weidman, J.R., Waterland, R.A., Jirtle, R.L., 2006. Maternal genistein alters coat color and protects Avy mouse offspring from obesity by modifying the fetal epigenome. Environ. Health Perspect. 114, 567-572. http://dx.doi.org/10.1289/ehp. 8700.

EFSA NDA Panel, 2009. Scientific Opinion on the substantiation of health claims related to folate and blood formation (ID 79), homocysteine metabolism (ID 80), energy yielding metabolism (ID 90), function of the immune system (ID 91), function of blood vessels (ID 94, 175, 192). EFSA J. 1213.

Egert, S., Wolffram, S., Bosy-Westphal, A., Boesch-Saadatmandi, C., Wagner, A.E., Frank, J., Rimbach, G., Mueller, M.J., 2008. Daily quercetin supplementation dose-dependently increases plasma quercetin concentrations in healthy humans. J. Nutr. 138, 1615-1621.

Eichholzer, M., Tönz, O., Zimmermann, R., 2006. Folic acid: a public-health challenge. Lancet (London, England) 367, 1352-1361. http://dx.doi.org/10.1016/S01406736(06)68582-6.

Euromonitor International, 2015. Young Women's Health: Global Attitudes towards Health. Fitness and Wellbeing Among the Under 30s and Market Impact. .

European Centre for Ecotoxicology and Toxicology of Chemicals, 2015. The Role of Epigenetics in Reproductive Toxicity. Workshop Report No. 30. Brussels. .

European Commission, 1997. 97/618/EC: Commission Recommendation of 29 July 1997 concerning the scientific aspects and the presentation of information necessary to support applications for the placing on the market of novel foods and novel food ingredients and the preparation of ini. Off J Eur Communities L 253, 1-36.

European Parliament and Council, 2002. Regulation (EC) No 178/2002 of the European Parliament and of the Council of 28 January 2002 laying down the general principles and requirements of food law, establishing the European Food Safety Authority and laying down procedures in matters of food saf. Off J Eur Communities L 31 (45), $1-24$.

European Parliament and Council of the European Union, 2015. Regulation (EU) 2015/ 2283 of the european parliament and of the Council of 25 november 2015 on novel foods, amending regulation (EU) No 1169/2011 of the european parliament and of the Council and repealing regulation (EC) No 258/97 of the european parliam. Off $\mathrm{J}$ Eur Union L 327, 1-22.

European Parliament and Council of the European Union, 2002. Directive 2002/46/EC of the european parliament and of the Council of 10 june 2002 on the approximation of the laws of the member States relating to food supplements. Off J Eur Communities L 183 (45), 51-57.

Fetahu, I.S., Höbaus, J., Kállay, E., 2014. Vitamin D and the epigenome. Front. Physiol. 5 , 164.

Friedman, J.M., 2000. Teratology society: presentation to the FDA public meeting on safety issues associated with the use of dietary supplements during pregnancy. Teratology 62, 134-137. http://dx.doi.org/10.1002/1096-9926(200008) 62:2<134::AID-TERA10 > 3.0.CO;2-D 
Gezondheidsraad, 2008. Naar Een Optimaal Gebruik Van Foliumzuur. Den Haag.

Gicquel, C., El-Osta, A., Le Bouc, Y., 2008. Epigenetic regulation and fetal programming. Best Pract. Res. Clin. Endocrinol. Metabol. 22, 1-16.

Gluckman, P.D., 2004. Living with the past: evolution, development, and patterns of disease. Science (80-) 305, 1733-1736. http://dx.doi.org/10.1126/science.1095292. Godfrey, K.M., Barker, D.J., 2001. Fetal programming and adult health. Publ. Health Nutr. 4, 611-624. http://dx.doi.org/10.1079/PHN2001145.

Godfrey, K.M., Lillycrop, K.A., Burdge, G.C., Gluckman, P.D., Hanson, M.A., 2013. Nonimprinted epigenetics in fetal and postnatal development and growth. Nestle Nutr. Inst. Workshop Ser. 71, 57-63. http://dx.doi.org/10.1159/000342552.

Godfrey, K.M., Lillycrop, K.A., Burdge, G.C., Gluckman, P.D., Hanson, M.A., 2007. Epigenetic mechanisms and the mismatch concept of the developmental origins of health and disease. Pediatr. Res. 61, 5R-10R.

Grandjean, P., 2008. Late insights into early origins of disease. Basic Clin. Pharmacol. Toxicol. 102, 94-99. http://dx.doi.org/10.1111/j.1742-7843.2007.00167.x.

Greenop, K.R., Miller, M., de Klerk, N.H., Scott, R.J., Attia, J., Ashton, L.J., Dalla-Pozza, L., Bower, C., Armstrong, B.K., Milne, E., 2014. Maternal dietary intake of folate and vitamins B6 and B12 during pregnancy and risk of childhood brain tumors. Nutr. Canc. 66, 800-809. http://dx.doi.org/10.1080/01635581.2014.916326.

Håberg, S.E., London, S.J., Stigum, H., Nafstad, P., Nystad, W., 2009. Folic acid supplements in pregnancy and early childhood respiratory health. Arch. Dis. Child. 94 180-184. http://dx.doi.org/10.1136/adc.2008.142448.

Haider, B.A., Bhutta, Z.A., 2015. Multiple-micronutrient supplementation for women during pregnancy. Cochrane Database Syst. Rev. http://dx.doi.org/10.1002/ 14651858.CD004905.pub4. CD004905.

Hambidge, K.M., Krebs, N.F., Westcott, J.E., Garces, A., Goudar, S.S., Kodkany, B.S., Pasha, O., Tshefu, A., Bose, C.L., Figueroa, L., Goldenberg, R.L., Derman, R.J., Friedman, J.E., Frank, D.N., McClure, E.M., Stolka, K., Das, A., Koso-Thomas, M. Sundberg, S., 2014. Preconception maternal nutrition: a multi-site randomized controlled trial. BMC Pregnancy Childbirth 14, 111.

Hilakivi-Clarke, L., Cho, E., Cabanes, A., DeAssis, S., Olivo, S., Helferich, W., Lippman, M.E., Clarke, R., 2002. Dietary modulation of pregnancy estrogen levels and breast cancer risk among female rat offspring. Clin. Canc. Res. 8, 3601-3610.

Hilakivi-Clarke, L., Cho, E., Onojafe, I., Raygada, M., Clarke, R., n.d. Maternal exposure to genistein during pregnancy increases carcinogen-induced mammary tumorigenesis in female rat offspring. Oncol. Rep. 6, 1089-1095.

Imhoff-Kunsch, B., Briggs, V., Goldenberg, T., Ramakrishnan, U., 2012. Effect of n-3 longchain polyunsaturated fatty acid intake during pregnancy on maternal, infant, and child health outcomes: a systematic review. Paediatr. Perinat. Epidemiol. 26 (Suppl. 1), 91-107. http://dx.doi.org/10.1111/j.1365-3016.2012.01292.x.

Kaiser, L., Allen, L.H., 2008. Position of the American Dietetic Association: nutiriotn and lifestyle for a healthy pregnancy outcome. J. Am. Diet Assoc. 108, 553-561.

Kim, H.J., Giovannucci, E., Rosner, B., Willett, W.C., Cho, E., 2014. Longitudinal and secular trends in dietary supplement use: nurses' health study and health professionals follow-up study, 1986-2006. J. Acad. Nutr. Diet. 114, 436-443. http://dx.doi. org/10.1016/j.jand.2013.07.039.

Knapik, J.J., Steelman, R.A., Hoedebecke, S.S., Austin, K.G., Farina, E.K., Lieberman, H.R., 2016. Prevalence of dietary supplement use by athletes: systematic review and meta-analysis. Sports Med. 46, 103-123. http://dx.doi.org/10.1007/s40279-0150387-7.

Ladipo, O.A., 2000. Nutrition in pregnancy: mineral and vitamin supplements. Am. J. Clin. Nutr. 72, 280S-290S.

Lillycrop, K.A., 2011. Effect of maternal diet on the epigenome: implications for human metabolic disease. Proc. Nutr. Soc. 70, 64-72.

Lillycrop, K.A., Burdge, G.C., 2014. Environmental challenge, epigenetic plasticity and the induction of altered phenotypes in mammals. Epigenomics 6, 623-636.

Magdelijns, F.J.H., Mommers, M., Penders, J., Smits, L., Thijs, C., 2011. Folic acid use in pregnancy and the development of atopy, asthma, and lung function in childhood. Pediatrics 128, e135-e144.

Martinussen, M.P., Risnes, K.R., Jacobsen, G.W., Bracken, M.B., 2012. Folic acid supplementation in early pregnancy and asthma in children aged 6 years. Am. J. Obstet. Gynecol. 206http://dx.doi.org/10.1016/j.ajog.2011.07.033. 72.e1-72.e7.

Mennen, L.I., Walker, R., Bennetau-Pelissero, C., Scalbert, A., 2005. Risks and safety of polyphenol consumption. Am. J. Clin. Nutr. 81, 326S-329S.

Menrad, K., 2003. Market and marketing of functional food in Europe. J. Food Eng. 56, 181-188. https://doi.org/10.1016/S0260-8774(02)00247-9.

Netting, M.J., Middleton, P.F., Makrides, M., 2014. Does maternal diet during pregnancy and lactation affect outcomes in offspring? A systematic review of food-based approaches. Nutrition 30, 1225-1241.

Osterhues, A., Ali, N.S., Michels, K.B., 2013. The role of folic acid fortification in neural tube defects: a review. Crit. Rev. Food Sci. Nutr. 53, 1180-1190.

Ota, E., Mori, R., Middleton, P., Tobe-Gai, R., Mahomed, K., Miyazaki, C., Bhutta, Z.A., 2015. Zinc supplementation for improving pregnancy and infant outcome. Cochrane Database Syst. Rev. 2http://dx.doi.org/10.1002/14651858.CD000230.pub5. CD000230.

Pauwels, S., Ghosh, M., Duca, R.C., Bekaert, B., Freson, K., Huybrechts, I., Langie, S.A.S., Koppen, G., Devlieger, R., Godderis, L., 2017. Maternal intake of methyl-group donors affects DNA methylation of metabolic genes in infants. Clin. Epigenet. 9, 16. http://dx.doi.org/10.1186/s13148-017-0321-y.

Picciano, M.F., McGuire, M.K., 2009. Use of dietary supplements by pregnant and lactating women in North America. Am. J. Clin. Nutr. 89http://dx.doi.org/10.3945/ ajcn.2008.26811B. 663S-7S.

Prater, M.R., Laudermilch, C.L., Liang, C., Holladay, S.D., 2008. Placental oxidative stress alters expression of murine osteogenic genes and impairs fetal skeletal formation. Placenta 29, 802-808.

Radimer, K., Bindewald, B., Hughes, J., Ervin, B., Swanson, C., Picciano, M.F., 2004. Dietary supplement use by US adults: data from the national health and nutrition examination survey, 1999-2000. Am. J. Epidemiol. 160, 339-349. http://dx.doi.org/ 10.1093/aje/kwh207.

Ramakrishnan, U., Grant, F., Goldenberg, T., Zongrone, A., Martorell, R., 2012. Effect of Women's nutrition before and during early pregnancy on maternal and infant outcomes: a systematic review. Paediatr. Perinat. Epidemiol. 26, 285-301.

Rihouey-Robini, E.A.L., 2014. France: new report on the French "nutrivigilance" mission since 2010. Eur. Food Feed Law Rev. 9 421-421.

Rock, C.L., 2007. Multivitamin-multimineral supplements: who uses them? Am. J. Clin. Nutr. 85, 277S-279S

Roseboom, T.J., Painter, R.C., van Abeelen, A.F.M., Veenendaal, M.V.E., de Rooij, S.R., 2011. Hungry in the womb: what are the consequences? Lessons from the Dutch famine. Maturitas 70, 141-145. http://dx.doi.org/10.1016/j.maturitas.2011.06.017.

Roseboom, T.J., van der Meulen, J.H.P., Ravelli, A.C.J., Osmond, C., Barker, D.J.P., Bleker, O.P., 2001. Effects of prenatal exposure to the Dutch famine on adult disease in later life: an overview. Mol. Cell. Endocrinol. 185, 93-98. http://dx.doi.org/10. 1016/S0303-7207(01)00721-3.

Schmidt, C., 2015. Dietary Supplements Increasingly Targeting Fertility.

Schüz, J., Weihkopf, T., Kaatsch, P., 2007. Medication use during pregnancy and the risk of childhood cancer in the offspring. Eur. J. Pediatr. 166, 433-441. http://dx.doi.org/ 10.1007/s00431-006-0401-z.

Schweitzer, A., 2006. Dietary supplements during pregnancy. J. Perinat. Educ. 15, 44-45. http://dx.doi.org/10.1624/105812406X107834.

Skibola, C.F., Smith, M.T., 2000. Potential health impacts of excessive flavonoid intake. Free Radic. Biol. Med. 29, 375-383.

Sullivan, K.M., Ford, E.S., Fuad Azrak, M., Mokdad, A.H., 2009. Multivitamin use in pregnant and nonpregnant women: results from the behavioral risk factor surveillance system. Publ. Health Rep. 124, 384-390.

Teichner, W., Lesko, M., 2013. Cashing in on the Booming Market for Dietary Supplements.

Tsui, B., Dennehy, C.E., Tsourounis, C., 2001. A survey of dietary supplement use during pregnancy at an academic medical center. Am. J. Obstet. Gynecol. 185, 433-437. http://dx.doi.org/10.1067/mob.2001.116688.

Turck, D., Bresson, J., Burlingame, B., Dean, T., Fairweather-Tait, S., Heinonen, M., Hirsch-Ernst, K.I., Mangelsdorf, I., McArdle, H., Naska, A., Neuhäuser-Berthold, M., Nowicka, G., Pentieva, K., Sanz, Y., Siani, A., Sjödin, A., Stern, M., Tomé, D., Vinceti, M., Willatts, P., Engel, K., Marchelli, R., Pöting, A., Poulsen, M., Salminen, S., Schlatter, J., Arcella, D., Gelbmann, W., Sesmaisons-Lecarré, A., Verhagen, H., Loveren, H., 2016. Guidance on the preparation and presentation of an application for authorisation of a novel food in the context of Regulation (EU) 2015/2283. EFSA J. 14.

U.S. Congress, n.d. Federal food, drug, and cosmetic act.

U.S. Food and Drug Administration, 2014. New dietary ingredients notification process new dietary ingredients in dietary supplements - background for industry [WWW document]. http://www.fda.gov/Food/DietarySupplements/ NewDietaryIngredientsNotificationProcess/ucm109764.htm, Accessed date: 14 July 2016.

Vanhees, K., Coort, S., Ruijters, E.J.B., Godschalk, R.W.L., van Schooten, F.J., Barjesteh van Waalwijk van Doorn-Khosrovani, S., 2011a. Epigenetics: prenatal exposure to genistein leaves a permanent signature on the hematopoietic lineage. FASEB. J. 25, 797-807. http://dx.doi.org/10.1096/fj.10-172155.

Vanhees, K., Godschalk, R.W., Sanders, A., van Waalwijk van Doorn-Khosrovani, S.B., van Schooten, F.J., 2011b. Maternal quercetin intake during pregnancy results in an adapted iron homeostasis at adulthood. Toxicology 290, 350-358. http://dx.doi.org/ 10.1016/j.tox.2011.10.017.

Vanhees, K., van Schooten, F.J., Moonen, E.J., Maas, L.M., van Waalwijk van DoornKhosrovani, S.B., Godschalk, R.W.L., 2012. Maternal intake of quercetin during gestation alters ex vivo benzo[a]pyrene metabolism and DNA adduct formation in adult offspring. Mutagenesis 27, 445-451. http://dx.doi.org/10.1093/mutage/ges002.

Vanhees, K., van Schooten, F.J., van Waalwijk van Doorn-Khosrovani, S.B., van Helden, S., Munnia, A., Peluso, M., Briedé, J.J., Haenen, G.R.M.M., Godschalk, R.W.L., 2013 Intrauterine exposure to flavonoids modifies antioxidant status at adulthood and decreases oxidative stress-induced DNA damage. Free Radic. Biol. Med. 57, 154-161.

Vanhees, K., Vonhögen, I.G.C., van Schooten, F.J., Godschalk, R.W.L., 2014. You are what you eat, and so are your children: the impact of micronutrients on the epigenetic programming of offspring. Cell. Mol. Life Sci. 71, 271-285. http://dx.doi.org/10. 1007/s00018-013-1427-9.

Velicer, C.M., Ulrich, C.M., 2008. Vitamin and mineral supplement use among US adults after cancer diagnosis: a systematic review. J. Clin. Oncol. 26, 665-673. http://dx. doi.org/10.1200/JCO.2007.13.5905.

Vickers, M.H., Breier, B.H., Cutfield, W.S., Hofman, P.L., Gluckman, P.D., 2000. Fetal origins of hyperphagia, obesity, and hypertension and postnatal amplification by hypercaloric nutrition. Am. J. Physiol. Endocrinol. Metab. 279, E83-E87.

Wang, T., Zhang, H.P., Zhang, X., Liang, Z.A., Ji, Y.L., Wang, G., 2015. Is folate status a risk factor for asthma or other allergic diseases? Allergy Asthma Immunol. Res. 7 , 538-546. http://dx.doi.org/10.4168/aair.2015.7.6.538.

Wardenaar, F.C., Ceelen, I.J., Van Dijk, J.-W., Hangelbroek, R.W., Van Roy, L., Van der Pouw, B., De Vries, J.H., Mensink, M., Witkamp, R.F., 2016. Nutritional supplement use by Dutch elite and sub-elite athletes: does receiving dietary counselling make a difference? Int. J. Sport Nutr. Exerc. Metabol. 1-25. http://dx.doi.org/10.1123/ ijsnem.2016-0157.

Warri, A., Saarinen, N.M., Makela, S., Hilakivi-Clarke, L., 2008. The role of early life genistein exposures in modifying breast cancer risk. Br. J. Canc. 98, 1485-1493. http://dx.doi.org/10.1038/sj.bjc.6604321.

Whitrow, M.J., Moore, V.M., Rumbold, A.R., Davies, M.J., 2009. Effect of supplemental folic acid in pregnancy on childhood asthma: a prospective birth cohort study. Am. J. Epidemiol. 170, 1486-1493. 